\title{
DNA signature of thermophilic bacteria from the aged accretion ice of Lake Vostok, Antarctica: implications for searching for life in extreme icy environments
}

\author{
Sergey A. Bulat ${ }^{1,2,3}$, Irina A. Alekhina', Michel Blot ${ }^{2 *}$, Jean-Robert Petit ${ }^{3}$, Martine \\ de Angelis ${ }^{3}$, Dietmar Wagenbach ${ }^{4}$, Vladimir Ya. Lipenkov ${ }^{5}$, Lada P. Vasilyeva', \\ Dominika M. Wloch², Dominique Raynaud ${ }^{3}$ and Valery V. Lukin ${ }^{5}$ \\ ${ }^{1}$ Division of Molecular and Radiation Biophysics, Petersburg Nuclear Physics Institute, Leningrad region, Gatchina \\ 188300, Russia \\ e-mail:bulat@omrb.pnpi.spb.ru \\ ${ }^{2}$ Plasticité et Expression des Génomes Microbiens, UJF, CNRS, Grenoble 38041, France \\ e-mail:sergev.bulat@uif-grenoble.fr. \\ ${ }^{3}$ Laboratoire de Glaciologie et de Géophysique de l'Environnement, CNRS, BP96, Saint Martin d'Hères 38402, France \\ ${ }^{4}$ Institut für Umweltphysik, INF 229 Heidelberg 69120, Germany \\ ${ }^{5}$ Arctic and Antarctic Research Institute, 38 Bering Str., St. Petersburg 199397, Russia
}

\begin{abstract}
We have used 16S ribosomal genes to estimate the bacterial contents of Lake Vostok accretion ice samples at $3551 \mathrm{~m}$ and $3607 \mathrm{~m}$, both containing sediment inclusions and formed $20000-15000$ yr ago. Decontamination proved to be a critical issue, and we used stringent ice chemistrybased procedures and comprehensive biological controls in order to restrain contamination. As a result, up to now we have only recognized one $16 \mathrm{~S}$ rDNA bacterial phylotype with confident relevance to the lake environment. It was found in one sample at $3607 \mathrm{~m}$ depth and represents the extant thermophilic facultative chemolithoautotroph Hydrogenophilus thermoluteolus of beta-Proteobacteria, and until now had only been found in hot springs. No confident findings were detected in the sample at $3551 \mathrm{~m}$, and all other phylotypes revealed (a total of 16 phylotypes, 336 clones including controls) are presumed to be contaminants. It seems that the Lake Vostok accretion ice is actually microbe-free, indicating that the water body should also be hosting a highly sparse life. The message of thermophilic bacteria suggests that a geothermal system exists beneath the cold water body of Lake Vostok, what is supported by the geological setting, the long-term seismotectonic evidence from ${ }^{4} \mathrm{He}$ degassing and the ${ }^{18} \mathrm{O}$ shift' of the Vostok accretion ice. The seismotectonic activity that seems to operate in deep faults beneath the lake could sustain thermophilic chemolithoautotrophic microbial communities. Such a primary production scenario for Lake Vostok may have relevance for icy planets and the approaches used for estimating microbial contents in accretion ice are clearly relevant for searching for extraterrestrial life.

Received 20 November 2003, accepted 4 March 2004
\end{abstract}

Key words: accretion ice, Antarctica, bacteria, contamination, exobiology, geothermal environment, Lake Vostok, subglacial lake environments, thermophiles.

\section{Introduction}

Lake Vostok is the Earth's largest subglacial lake among more than 70 subglacial water bodies so far detected in Antarctica (Kapitsa et al. 1996; Siegert 2000, 2001). It has been buried beneath a thick ice sheet for at least 15 million years (Barrett 2003) and by this raises exceptional interest for a search for organisms in a location that has been isolated from the Earth's surface for a very long period. The lake represents

* Deceased 8 September 2002. an extreme environment with a pressure close to 400 atmospheres, an ultra-low nutrient supply from the glacier melt, an ambient water temperature close to freezing (i.e. $-2.5^{\circ} \mathrm{C}$ ), and a possible excess of oxygen and nitrogen (Lipenkov \& Istomin 2001; McKay et al. 2003). Subglacial environments are expected on the Jovian satellite Europa, but as an ocean covered by an ice shell (Carr et al. 1998; Pappalardo et al. 1999) making Lake Vostok a terrestrial analogue.

A $3623 \mathrm{~m}$ Vostok ice core was drilled, mainly for paleoclimate studies (Petit et al. 1999). The bottom $80 \mathrm{~m}$ of the core is within a $215 \mathrm{~m}$ thick ice accretion layer, and the 3538-3623 m 
Table 1. Ice core samples studied

\begin{tabular}{|c|c|c|c|c|c|}
\hline Sample (\#) & Depth interval (m) & Physical characteristics & Initial weight $(\mathrm{g})$ & $\begin{array}{l}\text { Amount removed } \\
(\%)\end{array}$ & $\begin{array}{l}\text { rDNA clone } \\
\text { library }\end{array}$ \\
\hline \multicolumn{6}{|l|}{ Glacial ice core } \\
\hline \#3001 (F)* & $3000.00-3000.50$ & Poly-crystalline ice & 103.0 & 53.4 & 3001 \\
\hline \multicolumn{6}{|l|}{ Accretion ice core } \\
\hline \#3551 (F) & $3550.49-3550.89$ & $\begin{array}{l}\text { Mono-crystal with 2-3 mm } \\
\text { sediment inclusion }\end{array}$ & 35.0 & 38.0 & 3551 \\
\hline$\# 3607$ (F) & $3606.00-3606.54$ & $\begin{array}{l}\text { Mono-crystal with 5-6 mm } \\
\text { sediment inclusion }\end{array}$ & 22.0 & 55.0 & 3607 \\
\hline$\# 3607 b(F)$ & $3606.00-3606.54$ & Three-crystal boundaries & 40.3 & 61.0 & $3607 b$ \\
\hline \#3607c (RU) & $3606.545-3606.995$ & Mono-crystal & 137.0 & 37.2 & $3607 \mathrm{c}$ \\
\hline
\end{tabular}

*French (F) or Russian (RU) allotment.

horizon is derived from the lake water (Jouzel et al. 1999; Masolov et al. 2001), which provides ice core samples that currently offer the best template of the lake water contents.

Previous studies by microscopic observation, organic chemistry, DNA amplification, metabolic activity detection or culturing suggested that Lake Vostok might host life (Karl et al. 1999; Priscu et al. 1999; Abyzov et al. 2001; Christner et al. 2001). However, a major uncertainty in Lake Vostok geomicrobiological studies is the extent of ice core contamination by the drilling fluid and core handling (Vincent 1999 , 2000). Due to the very low biomass in Vostok ice samples (Bulat et al. 2002, 2003), searching for life there has proved to be constrained by a high chance of contamination in a similar manner to the forward-contamination ${ }^{1}$ which can occur when searching for life in very poor media in terms of the planetary protection policy (Space Studies Board 2000; Rummel 2001).

Therefore, confidence in biological ice core findings increases in value as long as: (i) the ice chemistry meets the standard for low-concentration measurements of polar ice; (ii) the molecular biology meets the standard of forensic science; (iii) the biological findings differ from those from the various environments in contact with the ice core; (iv) the biological findings are discussed with respect to the expected conditions of subglacial environments. A multidisciplinary approach to such a study is therefore the obvious imperative.

The stringent decontamination techniques currently used in ice core chemistry allow for reliable measurements of major ions as well as the trace elements (Boutron et al. 1994; Legrand \& Mayewski 1997) present in ice for central Antarctica at concentration levels of $10^{-9}$ and $10^{-12} \mathrm{~g} / \mathrm{g}$, respectively. In this work, we have applied a rigorous ice-chemistrybased decontamination procedure for Antarctic ice core samples to produce the most reliable chemical composition for major ions. For the samples that have satisfactorily passed the chemical control, we have implemented numerous and comprehensive biological controls to avoid misleading results.

We report here the results of a $16 \mathrm{~S}$ ribosomal gene study in estimating the bacterial contents of two samples of the aged Lake Vostok accretion ice at 3551 and $3607 \mathrm{~m}$.

\footnotetext{
${ }^{1}$ Accidental contamination of other worlds with microbes brought from Earth.
}

\section{Materials and methods}

Vostok ice core samples

The Vostok ice core samples studied were taken from accretion ice (at 3551 and $3607 \mathrm{~m}$ ) and one sample was taken from glacial ice (at $3001 \mathrm{~m}$ ) for comparison. The accretion ice horizon was found to contain small visible inclusions of sediment trapped when the glacier moved across a shallow embayment upstream of the Vostok site (Jouzel et al. 1999; refer also to Fig. 3 below).

The age of the glacial ice sample is about $300000 \mathrm{yr}$ (Petit et al. 1999). The accretion rate is about $1 \mathrm{~cm}^{2}$ annum ${ }^{-1}$ (Petit 2003; Petit et al. 2003), and at Vostok the total accretion ice is about $215 \mathrm{~m}$. These results in the samples \#3607 and \#3551, which are located at ca. 150 and $200 \mathrm{~m}$ from the water-ice interface, are $\sim 15000$ and 20000 years old, respectively.

Table 1 indicates the physical and decontamination characteristics of the selected samples and the generated rDNA clone libraries.

\section{Ice core decontamination procedure}

As a first step, ice cutting and surface cleaning were performed in a cold room $\left(-15^{\circ} \mathrm{C}\right)$ using an ethanol treated saw. Then, pre-treated ice samples were washed in triple stepby-step with exceptionally pure water $<2$ ppb C, ELGA PURELAB Maxima ${ }^{\circledR}$ with a $5 \mathrm{kDa}$ cutoff ultra filter (Vivendi Water Systems Ltd, UK) and melted in clean sterile polycarbonate straight-sided wide-mouth jars (Nalgene) at room temperature. Core washing was carried out within a class 100 laminar hood (EU-ISO-5) in a class 10000 (EUISO-7) dust-free laboratory and the laboratory personnel used surgical supplies (sterile cloths, gloves, masks and shields). Surfaces and tools were cleaned with decontamination solutions (e.g., Proline Biocontrol, Biohit).

Water aliquots were analysed by ion chromatography (Legrand et al. 1993). For dissolved organic carbon (DOC) measurements, ice core sub-samples were decontaminated by controlled fractional melting and consecutively analysed using a dedicated flow injection system coupled to a UVbased combustion $/ \mathrm{CO}_{2}$ monitor unit (Ultra TOC Astrolab), which featured a detection limit of less than $5 \mathrm{ppb}$ C.

The ice samples were prepared in a different building to that used for DNA extraction and PCR analyses in order 
to avoid any impact of PCR products on samples. The class 10000 dust-free laboratory was never used for DNA work.

\section{DNA extraction, 16S rDNA amplification, cloning, and sequencing}

The melt water of samples \#3001 and \#3607b were concentrated 780 and 2000 times, respectively, by centrifugal filtering through $3 \mathrm{kD}$ membranes (Pall Gelman and Millipore) and DNA was extracted (QIAamp DNA Mini kit, Qiagen). For samples with inclusions (\#3551 and \#3607), DNA extraction was performed directly from the sediment material containing melt water that was collected by centrifugation.

A semi-nested broad-range bacterial $16 \mathrm{~S}$ ribosomal DNA PCR was performed for 28 cycles with the $6 \mathrm{Fb}-787 \mathrm{Rb}$ primer pair $\left(10 \mathrm{~s}\right.$ at $93{ }^{\circ} \mathrm{C}, 40 \mathrm{~s}$ at $55^{\circ} \mathrm{C}, 60 \mathrm{~s}$ at $72^{\circ} \mathrm{C}$ with the first DNA melting at $93{ }^{\circ} \mathrm{C}$ for $3 \mathrm{~min}$ ) followed by 25 cycles with the $338 \mathrm{Fb}-787 \mathrm{Rb}$ primer pair under the same conditions (except for the final elongation step, 10 min at $72{ }^{\circ} \mathrm{C}$ ) using $0.3-0.5 \mu \mathrm{l}$ aliquots of primary PCR amplification. The universal primers were adapted from Godon et al. (1997), Teske et al. (1996), Muyzer et al. (1993) and McGregor et al. (1996) to cover representatives of most bacterial phylums: $6 \mathrm{Fb}$ (5'-GAAGAGTTTGATCCTGGCTC-3'), 338Fb (5'-ACHCCTACGGGDGRCWGCA-3') and 787Rb (5'-WGGACTACCIGRGTHTCTAAT-3').

The clones were only 405-430 bases in length because it was impossible to amplify full-sized 16S rRNA genes using different DNA polymerases and primers. This may be indicative of a very small amount of DNA or its ancient status (Cooper \& Poinar 2000) due to possible damage by, e.g., oxygen content in the lake (Lipenkov \& Istomin 2001). It is worth noting that the DNA was extracted from melt water concentrated about $\sim 1000$ times and we were nevertheless forced to use a very sensitive semi-nested PCR scheme to be able to generate signals. One-round PCR did not work, whilst PCR inhibitor tests performed with E. coli genomic DNA added to the original ice DNA samples were always negative.

PCR products embracing the V3 region of 16S rRNA genes were cloned into the TOPO TA (Invitrogen) or pGEM-T Easy (Promega) cloning vectors and the corresponding rDNA libraries were constructed (Table 1). After plating, up to 100 positive transformants per library were screened for inserts by PCR using flanking vector primers. The PCR products were cleaned with a kit (QIAquick PCR Purification Kit, Qiagen) and sequenced. A total of 128 405-431 base pair sized amplicons from ice sample libraries were sequenced. From these, seven chimeric sequences were detected both by visual inspection of corresponding alignments and by the Ribosomal Database Project II Chimera Check online tool (http://rdp.cme.msu.edu/cgis/chimera.cgi?su=SSU).

Preliminary control experiments performed by E. coli cell counting followed by PCR extinction showed that the detection limit of our PCR schemes was equivalent to ca. $5-8$ cells ml ${ }^{-1}$ of melt water.

In testing for Archaea, the same semi-nested ribosomal DNA PCR approach was implemented. The primers Ar4Fb (5'-TTCYSGTTGATYCYGCSRGA-3'), Ar347Fb
(5'- GGGYGCASCAGGCGCGAA-3'), 958Rb (5'-YCCGGCGTTGAMTCCAATT-3') and 1114Rb (5'-GGGTCTCGCYYGTTDCC-3') were adapted to cover representatives of the four known phylums of Archaea (Delong 1992; Burggraf et al. 1997; Huber et al. 2002) and tested in two different schemes: $\mathrm{Ar} 4 \mathrm{~F}-1114 \mathrm{R}$ primer combination followed by Ar4F-958R; and Ar4F-958R primer combination followed by Ar347F-958R. None of the schemes gave PCR products.

The sequences reported in this paper have been deposited in the GenBank database (accessions AF532058, AF532060, AF532061).

\section{Precautions and controls}

The five types of control for contaminant cells and dissolved DNA, inspected with PCR and DNA sequencing, were as follows. (i) Sham (negative) DNA extraction: (a) all reagents, spin filters and tubes (DNA extraction performed with PCR grade water (Invitrogen)); (b) TE buffer (ready-to-use, Sigma) made with Molecular Biology grade water (MoBio) and used for DNA elution. (ii) Negative PCR: PCR reagents including DNA polymerases that generate PCR products with no template DNA added. (iii) Ice core wash water. (iv) Original Vostok drilling fluid from different depths in the borehole. (v) Laboratory environment: dust collected with sterile tampons and soaked with ice core wash water or Molecular Biology grade water (MoBio) (in both the French and Russian biological laboratories).

For all five controls, corresponding rDNA libraries were constructed as described above and a total of 224 expectedsize clones were sequenced (of these, nine sequences were discarded as chimeric). By this procedure, a contaminant database was established. Separate contaminant datasets included 21 from the washing water, 118 from the laboratory environment, 31 from the drilling fluid, and 27 and 18 from negative PCR and sham DNA extraction, respectively. In addition, any known contaminant clones deposited into public databases (e.g., by Norman Pace) or published elsewhere (e.g., Tanner et al. 1998; Cisar et al. 2000; Kawai et al. 2002; Kulakov et al. 2002) were employed.

Bacterial species delineation was conducted more strictly than recommended (Stackebrandt \& Goebel 1994) because we worked on one-third of the rRNA gene sequence and a maximum of $2 \%$ sequence divergence was used to restrict overestimation of species limits.

\section{Phylogenetic analyses}

Neighbouring sequences were determined with the BLAST (Altschul et al. 1997) and FASTA (Pearson 1990) programs from public databases (GenBank). Sequences were aligned using the Clustalw program (Higgins et al. 1994).

Phylogenetic trees were estimated using the maximum parsimony, the minimum evolution (LogDet/paralinear distance parameter correction) and the maximum likelihood criteria in PAUP (version 4.0b10) (D. Swofford, Sinauer Associates). The trees obtained were analysed with the KishinoHasegawa test in order to select the best, which were then consequently optimized under the maximum likelihood criterion. 
Bootstrap values were obtained by the maximum-parsimony method on 100 replicates with random-order sequence additions.

For phylogeny reconstruction, aligned sequence blocks were fully cleaned for deletions or insertions, unassigned bases and ambiguous local alignments. Species limits depicted in a tree were defined using $3 \%$ sequence divergence $(0.03$ substitutions per site) (Stackebrandt \& Goebel 1994).

\section{Results and discussion}

The ice chemistry

Major ion and light carboxylic acid concentrations are sensitive to gaseous contamination from the laboratory environment (Legrand et al. 1993) and served as a first control for our decontamination procedures for the samples prior to molecular biological studies. For the lower part of the Vostok ice core $(>3520 \mathrm{~m})$, an initial reference profile of major ion and light carboxylic acid concentrations of glacial and accretion ice samples revealed very low contents of $\mathrm{NH}_{4}{ }^{+}$ (0.1-4 ppb), $\mathrm{NO}_{2}^{-}(<0.1 \mathrm{ppb})$, acetate $(0.5-2 \mathrm{ppb})$ and formate ions $(<0.5 \mathrm{ppb})$, which are consistent with those previously found in other Antarctic cores (Legrand \& Saigne 1988). In addition, the concentration of DOC, which is influenced by the presence of kerosene from the drilling fluid, was shown to be low and similar in both glacial $(24 \pm$ $14 \mathrm{ppb}$ C) and accretion $(17 \pm 7$ ppb C) ice, indicating clean samples. These data are consistent with the low carbon contribution from the light carboxylic acids and the values lie well below other data reported for accretion ice (80500 ppb C) (Karl et al. 1999; Priscu et al. 1999). The samples studied here for biology contained $10.7 \mathrm{ppb} \mathrm{C}$ (glacial ice at $3001 \mathrm{~m}$ ) and $12.5 \mathrm{ppb} \mathrm{C}$ (accretion ice at $3607 \mathrm{~m}$ ). The DOC content of the accretion ice at $3551 \mathrm{~m}$ was not determined.

\section{The biological aspect}

As shown earlier, the decontamination procedure that we followed is reliable for ice core chemical analyses (e.g., major ions). However, even when using ultra-pure water the core washing may be not efficient enough for removing all biological aliens (e.g., Kawai et al. 2002; Kulakov et al. 2002). In addition, commercial DNA extraction and PCR enzymes, reagents and disposable plastic articles suitable for use under low biomass conditions are not yet always certified DNA-free (e.g., Corless et al. 2000; Millar et al. 2002; Grahn et al. 2003). That is why we have established our own contaminant database and used DNA sequencing approach in order to decipher potential contaminants from the original ice signals as confidently as possible.

Ice core findings against contaminant database

The water used for ice washing, the original drilling fluid, the biological laboratory environment, sham DNA extraction and negative PCR controls were all monitored using the established contaminant database. Bacterial taxa identified by $16 \mathrm{~S}$ ribosomal DNA sequences in ice samples were indexed on the basis of six criteria, of which the contaminant database forms
Table 2. Indexing contaminant criteria for bacteria recorded in Vostok ice core

\begin{tabular}{|c|c|}
\hline $\begin{array}{l}\text { Key } \\
\text { Score }\end{array}$ & Regulation \\
\hline $\mathrm{A} * * * * *$ & $\begin{array}{l}\text { Taxa recorded in our contaminant database (refer to } \\
\text { Methods). A } 1 \text { - Ice core wash water, A2 - Original } \\
\text { Vostok drilling fluid, A3 - Laboratory environment. }\end{array}$ \\
\hline $\mathrm{B}^{* * * * *}$ & $\begin{array}{l}\text { Taxa proved to be contaminants (e.g., Tanner et al. 1998; } \\
\text { Cisar et al. 2000; Kawai et al. 2002; Kulakov et al. 2002). }\end{array}$ \\
\hline $\mathrm{C}^{* * *}$ & $\begin{array}{l}\text { Bacteria able to metabolize aliphatic and aromatic } \\
\text { hydrocarbons (present in e.g. kerosene). }\end{array}$ \\
\hline $\mathrm{D}^{* * *}$ & $\begin{array}{l}\text { Human/animal/plant saprophytes, commensals and } \\
\text { pathogens (and those associated with human activity } \\
\text { including food, etc.). }\end{array}$ \\
\hline $\mathrm{E}^{*}$ & $\begin{array}{l}\text { Taxa revealed in wastewater, activated sludge, } \\
\text { contaminated aquifer etc. (linked to human activity). }\end{array}$ \\
\hline $\mathrm{F}^{*}$ & $\begin{array}{l}\text { Taxa revealed in other glaciers. In the present study } \\
\text { F1 - GenBank accession No. AF479378, Taylor Dome, } \\
\text { Antarctica, F2 - No. AF479381, Taylor Dome, } \\
\text { Antarctica, F3 - No. AF479368, Sajama, Bolivia. }\end{array}$ \\
\hline
\end{tabular}

* low Confidence, $* * *$ confident, $* * * *$ high confidence, $* * * * *$ highest confidence.

a powerful but singular decisive factor (Table 2). Since the biological composition of Lake Vostok is hard to presume, a degree of confidence was introduced into the table allowing us to discard obvious cases with the highest score as contaminants, while those with lowest score refer to likely contaminants.

A total of 215 rDNA clones from various controls and 121 clones from both accretion (\#3551:6 and \#3607:26, \#3607b:53, \#3607c:16) and glacial (\#3001:20) ice were kept for further analyses. The ice clones showed high redundancy resulting in the recognition of twenty $16 \mathrm{~S}$ rDNA phylotypes, of which 16 were seen in the accretion ice and three of these were also found in the glacial ice. We only discuss the question of accretion ice findings here. Most phylotypes in accretion ice had close GenBank homologues (>98\%), i.e. were identified or assigned to known sequences, but three were distinctly different from their nearest neighbours ( $<96 \%$ similarity). Thirteen of the 16 phylotypes in accretion ice were indexed as contaminants and two extra phylotypes were regarded as additional likely contaminants because of their uncertain status (Table 3).

No species passing the contamination test were found in both the glacial and the accretion ice, suggesting a small probability of microbes transiting from the 1000000 year old (Salamatin et al. 2003) glacier melt water into the lake and becoming refrozen in accretion ice (Siegert et al. 2001). In addition, it is worth noting that we have no confident findings from glacier ice sample \#3001 (Bulat et al., unpublished) possibly due to the presence of dissolved oxygen in the ice matrix (about $1.0 \mathrm{O}_{2} \mathrm{mg} \mathrm{1}^{-1}$ ) (Ikeda et al. 2000; Lipenkov et al. 2002).

It is of interest that amongst the contaminants that we found in the ice (as proved by our contaminant database and N. Pace negative DNA extraction control AF058372), (Table 3, F1-F3), some showed a high similarity (up to $100 \%$ ) to a sequence with bacteria previously published from a 3593 m core (Table 2, key F). 
Table 3. Bacterial 16S rDNA clones recovered from Vostok ice core and presumed to be contaminants

\begin{tabular}{|c|c|c|c|c|c|c|c|}
\hline \multicolumn{5}{|c|}{ Number of allelic clones ${ }^{\mathrm{a}}$ in rDNA clone library } & \multirow{2}{*}{$\begin{array}{l}\text { Closest neighbours } \\
\text { in GenBank }\end{array}$} & \multirow{2}{*}{$\begin{array}{l}\text { Contamination } \\
\text { criterion }\end{array}$} & \multirow[b]{2}{*}{ Total score ${ }^{\mathrm{b}}$} \\
\hline 3607 & $3607 \mathrm{~b}$ & $3607 \mathrm{c}$ & 3551 & 3001 & & & \\
\hline \multicolumn{8}{|c|}{ Alpha-Proteobacteria } \\
\hline \multirow[t]{2}{*}{3} & & & 1 & & $\begin{array}{l}100 \% \text { Sphingomonas } \\
\text { paucimobilis (U37337) }\end{array}$ & $\mathrm{A} 3, \mathrm{C}, \mathrm{F} 1$ & 9 \\
\hline & 3 & & & & $\begin{array}{l}98-100 \% \text { Sphingobium } \\
\text { yanoikuyae (AY047219) }\end{array}$ & $\mathrm{A} 3, \mathrm{C}$ & 8 \\
\hline 1 & 8 & & & & $\begin{array}{c}99-100 \% \text { Sphingomonas } \\
\text { natatoria }(\mathrm{AB} 024288)\end{array}$ & $\mathrm{A} 2, \mathrm{~F} 2$ & 6 \\
\hline \multirow[t]{2}{*}{3} & & & & 4 & $\begin{array}{l}99-100 \% \text { Uncultured } \\
\text { bacterium D from beetle } \\
\text { larva intestine (AJ459874) }\end{array}$ & $\mathrm{D}$ & 3 \\
\hline & 2 & & & & $\begin{array}{l}99.8 \% \text { Uncultured bacterium } \\
\text { clone E6 from shower } \\
\text { curtain biofilms (AY268237) }\end{array}$ & $\mathrm{D}$ & 3 \\
\hline \multicolumn{8}{|c|}{ Beta-Proteobacteria } \\
\hline & 2 & & & & $\begin{array}{l}\text { 97\% rDNA clone } \\
\text { pACH94 (AY297809) }\end{array}$ & & \\
\hline & & & & & $\begin{array}{l}\text { 96\% Rhodocyclus sp. } \\
\text { R6 (AJ224937), rDNA } \\
\text { clones (AF204245), } \\
\text { (AF502232), (AF204244) }\end{array}$ & $\begin{array}{l}\text { Linked to } \mathrm{E} \\
\text { Likely contaminant } \\
\text { (AF532058) }\end{array}$ & $\mathrm{NA}^{\mathrm{c}}$ \\
\hline \multicolumn{8}{|c|}{ Gamma-Proteobacteria } \\
\hline \multirow[t]{3}{*}{1} & 4 & & 1 & & $\begin{array}{l}\text { 98-99\% Acinetobacter } \\
\text { johnsonii (X89775) }\end{array}$ & A3 & 5 \\
\hline & & 2 & & & $\begin{array}{l}99 \% \text { Pseudomonas } \\
\text { rhodesiae (AF064459) }\end{array}$ & $\mathrm{B}$ & 4 \\
\hline & & 6 & & & $\begin{array}{l}98 \% \text { Haemophilus } \\
\text { parainfluenzae (M75081) }\end{array}$ & $\mathrm{D}$ & 3 \\
\hline \multicolumn{8}{|c|}{ Delta-Proteobacteria } \\
\hline & 1 & & 1 & 1 & $\begin{array}{l}\text { 92-93\% Chondromyces } \\
\text { apiculatus (AJ233938), } \\
\text { C. robustus (AJ233941) }\end{array}$ & A3 & 5 \\
\hline \multicolumn{8}{|c|}{ Actinobacteria } \\
\hline & 1 & & & 3 & $\begin{array}{l}98 \% \text { Micrococcus } \\
\text { luteus (AJ409096) }\end{array}$ & $\mathrm{B}, \mathrm{F} 3$ & 5 \\
\hline \multirow[t]{2}{*}{1} & & & & & $\begin{array}{l}100 \% \text { Brevibacterium } \\
\text { iodinum }(\mathrm{X} 83813), \\
\text { B. epidermidis }(\mathrm{X} 76565)\end{array}$ & $\mathrm{D}$ & 3 \\
\hline & & 1 & & & $\begin{array}{l}\text { 99-100\% Microbacterium } \\
\text { sp. oral clone } \\
\text { AV005b (AF385527) }\end{array}$ & $\mathrm{D}$ & 3 \\
\hline \multicolumn{8}{|c|}{ Firmicutes } \\
\hline & 2 & & & & $\begin{array}{l}99 \% \text { Abiotrophia } \\
\text { defectiva (D50541) }\end{array}$ & $\mathrm{D}$ & 3 \\
\hline \multicolumn{8}{|c|}{ OP11 Candidate division } \\
\hline 3 & & & & & $\begin{array}{l}91.7 \% \text { Uncultured } \\
\text { soil bacterium } \\
\text { C011 (AF507682) }\end{array}$ & $\begin{array}{l}\text { Linked }^{\mathrm{d}} \text { to } \mathrm{A} 1 \text { and } \mathrm{E}^{\mathrm{e}} \\
\text { Likely contaminant } \\
\text { (AF532061) }\end{array}$ & $\mathrm{NA}^{\mathrm{c}}$ \\
\hline
\end{tabular}

${ }^{a}$ Differs by $1-5$ nucleotides within a phylotype.

${ }^{b}$ Refer to Table 2.

c Non applicable.

d Both, ice clones and 'A1' clone, showed the same low level similarity to soil bacterial rDNA clones of one location (Dunbar et al. 2002; Kuske et al. 1997; Swaty et al. 1998).

${ }^{\text {e }}$ Contaminated aquifer (N. Pace, unpublished).

\section{Confident findings}

Only one 16S rDNA phylotype (12 clones; two sequence types differing by one nucleotide substitution) successfully passed our contaminant database and other contaminant screening criteria (Table 2). The sequences were all found in only one sample at a depth of $3607 \mathrm{~m}$ (\#3607b). No confident findings were detected in ice core samples \#3551, \#3607 and \#3607c. 
Table 4. Taxonomic identification of clone $L V 3607 b R-40 A^{\text {a }}$ recovered from ice sample \#3607b

\begin{tabular}{|c|c|c|c|c|c|c|}
\hline \multicolumn{7}{|c|}{ Closest neighbours and their features } \\
\hline $\begin{array}{l}\text { GenBank }^{b} \\
\text { similarity }(\%)\end{array}$ & Acc. No. & Representative & Sampling site & $\begin{array}{l}\text { Temperature } \\
\text { profile }\end{array}$ & Source & Refs \\
\hline 100 & AB009828 & $\begin{array}{l}\text { Hydrogenophilus } \\
\text { thermoluteolus } \mathrm{TH}-1\end{array}$ & $\begin{array}{l}\text { Hot springs, } \\
\text { Izu district, Japan }\end{array}$ & $52^{\circ} \mathrm{C}^{\mathrm{c}}$ & $\begin{array}{l}\text { Crustal fluid, } \\
\text { adjacent soil }\end{array}$ & 1,2 \\
\hline 99.5 & AJ131694 & $\begin{array}{l}\text { Hydrogenophilus } \\
\text { hirschii yel5a }\end{array}$ & $\begin{array}{l}\text { Angel Terrace } \\
\text { Spring, } \\
\text { Yellowstone } \\
\text { National Park, USA }\end{array}$ & $50-67^{\circ} \mathrm{C}$ & Crustal fluid & 3 \\
\hline 99.1 & АВ009829 & $\begin{array}{l}\text { Hydrogenophilus } \\
\text { thermoluteolus } \mathrm{TH}-4\end{array}$ & $\begin{array}{l}\text { Hot springs, } \\
\text { Izu district, Japan }\end{array}$ & $50{ }^{\circ} \mathrm{C}^{\mathrm{c}}$ & $\begin{array}{l}\text { Crustal fluid, } \\
\text { adjacent soil }\end{array}$ & 1,2 \\
\hline 96.3 & AF026979 & $\begin{array}{l}\text { Unidentified } \\
\text { beta-proteobacterium } \\
\text { OPB30 (rDNA study only) }\end{array}$ & $\begin{array}{l}\text { Obsidian Pool, } \\
\text { Yellowstone } \\
\text { National Park, USA }\end{array}$ & $75-95^{\circ} \mathrm{C}$ & Sediments & 4 \\
\hline
\end{tabular}

\footnotetext{
${ }^{a}$ Representative of phylotype (AF532060, 12 clones, two sequence types differing by one nucleotide substitution).

${ }^{\mathrm{b}}$ Only full-sized and published $16 \mathrm{~S}$ rDNA sequences are included in the analysis.

${ }^{\mathrm{c}}$ Temperature profile for culturing.

[1] Goto et al. (1977); [2] Hayashi et al. (1999); [3] Stohr et al. (2001); [4] Hugenholtz et al. (1998).
}

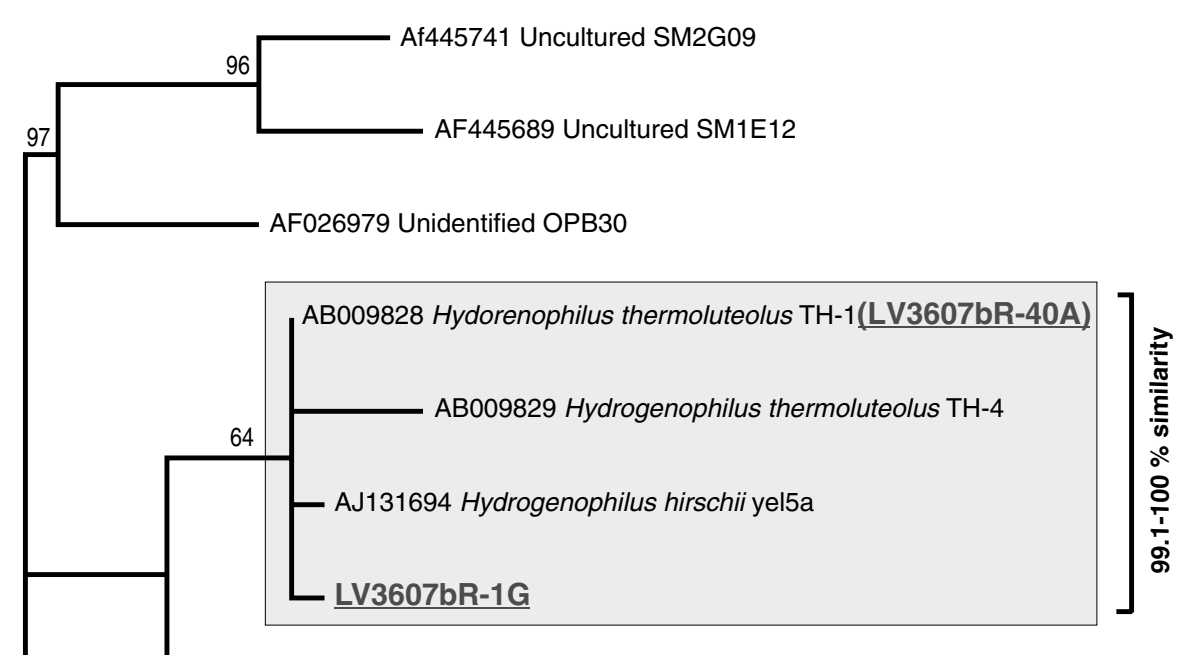

AF402975 Uncultured Hydrogenophilus bacteriap16

\section{AY219714 Petrobacter succinimandens}

\subsection{1 substitutions/site}

Fig. 1. Phylogenetic analysis of the bacterial rDNA clone LV3607bR-40A (a 428 nucleotide mask of unambiguously aligned positions) recovered from accretion ice sample \#3607b (Table 4). The clone LV3607bR-1G represents the 2nd sequence type of the phylotype differing by one nucleotide substitution. Bootstrap values of more than $50 \%$ are shown at the nodes. Ice clones are in bold and underlined font styles. Species limit is depicted with transparent boxes. Clone 3607bR-40A displays a sequence identical to AB009828.

(The image can be viewed in colour at http://lgge.obs.ujf-grenoble.fr/axes/glaciobiology.)

The phylotype depicted by the clone LV3607bR-40A represents the extant thermophilic bacterium Hydrogenophilus thermoluteolus (beta-Proteobacteria) that until recently was only encountered in hot springs in Izu district (Japan) with closely related species $H$. hirschii known for the hot springs of Yellowstone National Park, USA (Fig. 1, Table 4). Potentially, it is capable of growing as a chemolithoautotroph by oxidizing $\mathrm{H}_{2}$ and reducing $\mathrm{CO}_{2}$ (Goto et al. 1977; Hayashi et al. 1999; Stohr et al. 2001).

A sequence of rDNA ascribed to the genus Hydrogenophilus was also recently recovered by López-García et al.
(2003) from hydrothermal sediment at the Mid-Atlantic ridge. It was reported that this was the first time that members of this genus have been detected in deep-sea vents. In addition to the absence of Hydrogenophilus sp. in our contaminant database as well as from other known contaminant data (Table 2), the limited distribution of closest relatives of this species at the world scale (Table 4) provides an additional indication supporting its non-contaminant status.

It is worth noting that thermophilic bacterium Hydrogenophilus thermoluteolus was detected in a sample with crystal boundaries (\#3607b), while analysis of extra mono-crystal 
samples with (\#3607) and without (\#3607c) sediment inclusions did not give any confident signal. Because the bacterium we have found is a thermophilic species with an optimal growth temperature of around $50{ }^{\circ} \mathrm{C}$ (Goto et al. 1977; Hayashi et al. 1999), we explain its occurrence in the ice as an indication of the long-term concentration of microbes at the crystal boundaries by a freezing process, rather than the bacterium thriving in ice veins as suggested by Price (2000).

\section{Unclassified findings}

As mentioned above, three of the 16S rDNA phylotypes recovered in the Vostok ice core samples could not be identified because of their low similarity to sequences in GenBank. One species related to Chondromyces sp. of delta-Proteobacteria (Table 3) was also detected in our contaminant database, thus representing obvious contamination. However, two other phylotypes from different samples of accretion ice at $3607 \mathrm{~m}$ showed no clear counterparts amongst contaminants, but nevertheless they were regarded as likely contaminants (Table 3).

Phylogenetic analysis showed that the first phylotype (two clones; two sequence types differing by three nucleotide substitutions) is most related by a sequence to one uncharacterized clone detected in waterlogged archaeological wood (AY297809, 97\% similarity) and polyphosphate-accumulating strains ( $96 \%$ similarity) of the Rhodocyclus group with phototrophic beta-Proteobacteria affiliation (Crocetti et al. 2000), but demonstrates no confident clustering with these strains (Fig. 2(a)).

Most phototrophic beta-Proteobacteria of the genera Rhodocyclus, Rubrivivax and Rhodoferax are mesophilic and neutrophilic freshwater bacteria with optimal growth temperatures of between 25 and $30^{\circ} \mathrm{C}$. The species of Rhodocyclus, Rhodoferax and Rubrivivax are facultative anaerobic bacteria that preferably grow under anoxic conditions by anoxygenic photosynthesis. All of the species grow photoheterotrophically and most of the species are able to grow photoautotrophically with hydrogen as a reducing power for $\mathrm{CO}_{2}$ fixation. They all are able to grow aerobically to microaerobically in the dark by oxygen-dependent respiration (Imhoff 2003). However, because the phototrophic beta-Proteobacteria are common in stagnant waters (freshwater ponds, sewage ditches and activated sludge) that are enriched by organic compounds and nutrients and exposed to light (Imhoff 2003), it is unlikely that the phylotype recovered in ice is representative of lake biota although it has lower DNA $\mathrm{G}+\mathrm{C}$ contents when compared with all tested relatives (about 53 and $56 \%$, respectively) and by this may represent a separate lineage.

The second phylotype (three clones; three sequence types differing by two nucleotide substitutions each) provide a more complex story. It showed rather distant relationships with an uncultured bacteria of the OP11 candidate division and is confidently clustered with an rDNA PCR clone from a hot, dry, nutrient-poor sandy-loam (sandstone and limestone) soil environment near the Sunset Crater, Arizona, USA (91.7\% sequence similarity) (Kuske et al. 1997; Swaty et al. 1998; Dunbar et al. 2002; see also Fig. 2(b)). All of the closest representatives from GenBank are uncultured and distant relatives of each other and ice clones, thus leaving this bacterial finding unresolved in terms of its taxonomy, features and living conditions.

However, in our contaminant database (the ice core wash water dataset), one clone-phylotype (E2-27) was detected which also demonstrated a low-score $(85 \%)$ similarity to the same set of soil bacterial clones (Sunset Crater, Arizona, USA) and OD1 clones sampled in a contaminated aquifer (N. Pace, unpublished) while showing no evident relatedness to the ice phylotype (76-77\% sequence similarity) (Fig. 2b). Nevertheless, because we are now increasingly aware of possible bacterial contamination, the presence of a contaminant phylotype that shares the same set of soil bacterial clones may be indicative of a contaminant status for the ice phylotype (Table 3).

Of the two distantly related phylotypes, the latter related to OP11 candidate division has a better chance of originating from the ice. However, due to the largely uncharacterized nature of microbial habitats in the biosphere, the environmental versatility of closely related species and the ubiquity of some microbial genera predictions of physiology based solely on 16S rDNA similarity, especially low similarity values, must be interpreted very cautiously.

\section{Deliberations}

Various bacteria previously discovered in Vostok accretion ice (Karl et al. 1999; Priscu et al. 1999; Abyzov et al. 2001; Christner et al. 2001) and identified by terminal restriction fragment length polymorphism (Priscu et al. 1999) and by 16S rRNA gene sequencing (Christner et al. 2001) have suggested the presence of life in Lake Vostok. In our approach we identified only one bacterium (12 clones; two sequence types differing by one nucleotide substitution) which successfully passed stringent contaminant criteria and, hence, can be considered as relevant to the accretion ice contents. This indicates that contamination, most from the laboratory environment (dust) as well as human sources (Table 3), even after rigorous decontamination procedures, is still an important source of foreign bacteria. This fact along with the inability to generate PCR products in one round of PCR indirectly suggests a very low number of cells and/or DNA amount in the Vostok accretion ice.

Our findings are of special interest because the bacterium we discovered represents a genuine thermophilic species. Taking into consideration the limits of any PCR approach (e.g., PCR bias in estimating species composition and diversity (Dunbar et al. 2002; Lueders \& Friedrich 2003)) and despite the fact that we do not know enough about the correlation between rRNA sequence type and phenotype (though we obtained $100 \%$ sequence similarity for the region studied) we regard our finding of Hydrogenophillus thermoluteolus as an indication of the geothermal environment beneath Lake Vostok. It is known that in such an environment, Archaea may be present (e.g., Barns et al. 1996). However, until now we have obtained no indication of them whilst the 


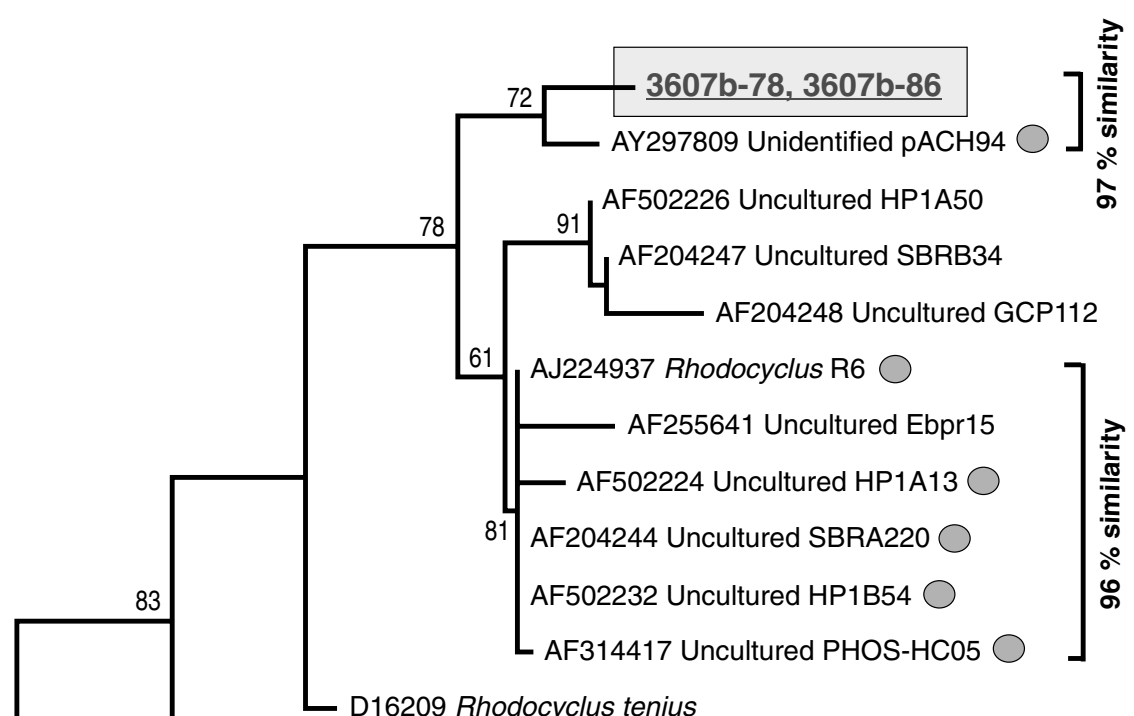

D16209 Rhodocyclus tenius

D16208 Rhodocyclus tenius

AF170348 Dechlorosoma suillum

AF016690 Propionibacter pelophilus

(a)
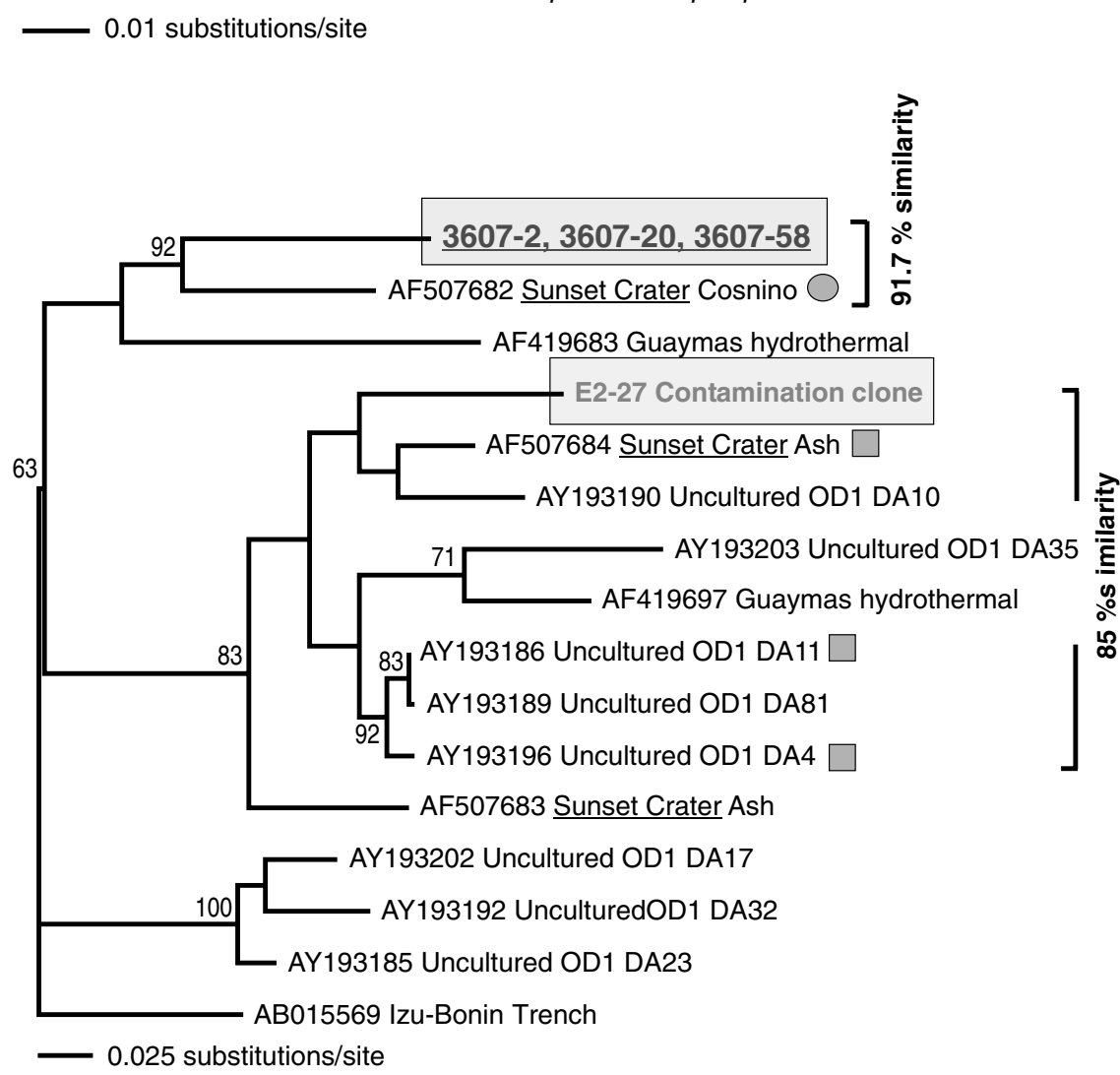

(b)

Fig. 2. Phylogenetic analysis of the bacterial rDNA clones recovered in $3607 \mathrm{~m}$ accretion ice and recorded as likely contaminants (Table 3). Bootstrap values of more than $50 \%$ are shown at the nodes. Species limits are depicted with transparent boxes. Sequences from GenBank with the highest similarity score (\%) are labelled with full circles (concerning ice clones) or squares (concerning contaminants). Ice clones are in bold and underlined font styles. (a) Phylogenetic tree (a 428 nucleotide mask of unambiguously aligned positions) for ice clones related to Rhodocyclus sp. (b) Phylogenetic tree (a 403 nucleotide mask of unambiguously aligned positions) for ice clones related to OP11 candidate division soil strains. OD1 clones were sampled from a contaminated aquifer (N. Pace, unpublished). Contaminant clone is in bold font style. Soil clones from Sunset Crater are in underlined font style. (The image can be viewed in colour at http://gge.obs.ujf-grenoble.fr/axes/ glaciobiology.) 


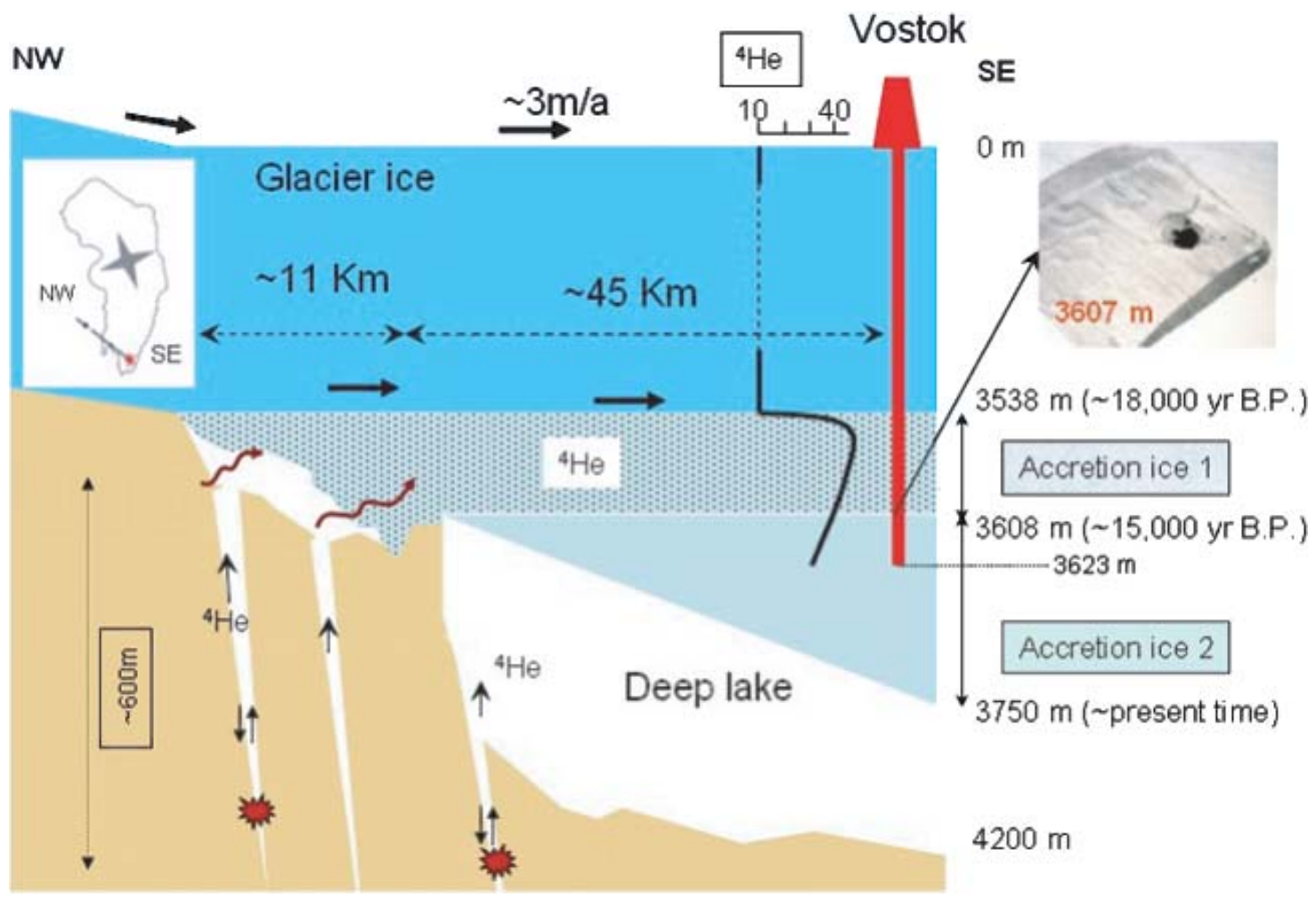

Fig. 3. Sketch of the glacier and lake basement along the Vostok ice flowline (adapted from Jouzel et al. 1999). On the $3623 \mathrm{~m}$ Vostok ice core, the accreted ice interval from 3538 to $3608 \mathrm{~m}$ depth (accretion ice 1) contains visible sediment inclusions (clay and mica aggregates) (insert on the right). Deeper ice and likely that ice all the way down to the glacier-water interface (accretion ice 2) are clean. Glacier flows are at about $3 \mathrm{~m}$ per year from the North-West to South-East (Bell et al. 2002) and the accreted ice 1 was formed approximately 15000-20000 years ago. A rise in relief is located at about $11 \mathrm{~km}$ enfolding a shallow depth embayment (Bell et al. 2002) where sediments could become incorporated into accreted ice (Jouzel et al. 1999). The rock basement is represented by escarpments, where deep faults allow water to seep to depth, become heated and then circulate. Fault activity and ${ }^{4} \mathrm{He}$ degassing from the rocks are depicted by an explosion symbol and vertical arrows, respectively. A sketch of down core ${ }^{4} \mathrm{He}$ concentration (Jean Baptiste et al. 2001) shows a constant value for glacial ice and a change by a factor of three at the glacier-accretion ice boundary. In accretion ice, a decreasing trend is observed from $38.5 \mathrm{nmole} \mathrm{kg}^{-1}$ at a depth of $3551 \mathrm{~m}$ to $35.5 \mathrm{nmole} \mathrm{kg}^{-1}$ at a depth of $3608 \mathrm{~m}$ suggesting ${ }^{4} \mathrm{He}$ contribution from the shallow embayment area upstream of Lake Vostok. (The image can be viewed in colour at http://lgge.obs.ujf-grenoble.fr/axes/glaciobiology.)

updated primers and more sophisticated PCR schemes were tested. It is worth noting that Priscu and co-workers did not detect Archaea in accretion ice as well (Priscu et al. 1999).

\section{The geophysical aspect}

The apparent geothermal environment beneath Lake Vostok is counterintuitive for such a site. The absence of ${ }^{3} \mathrm{He}$ isotope enrichment in accretion ice with respect to the glacial ice excludes the possibility of a contribution from mantle-derived hydrothermal fluids (e.g., black smokers) (Jean Baptiste et al. 2001, 2003). However, three indices lend support to geothermal activity, just not necessarily mantle derived.

A first indicator is the geological setting. The lake is $\sim 1200 \mathrm{~m}$ deep and lies in a depression within the thick continental basement: its sharp shores (Masolov et al. 2001) and likely U-shaped cross-section imply deep faults (Fig. 3) where water could seep to a great depth, heat up $\left(\sim 20^{\circ} \mathrm{C} \mathrm{km}^{-1}\right)$ and rise back to the lake causing hydrothermal circulation.

The second indicator is the long-term tectonic activity. The earthquakes observed from a fault within the lake have been used to support the possible introduction of energy into the lake, thereby fuelling hydrothermal circulation (Studinger et al. 2003). Past activity is supported by ${ }^{4} \mathrm{He}$ isotope measurements. A three-fold ${ }^{4} \mathrm{He}$ excess in the ca. 15000 year old accretion ice is observed with respect to the overlying glacial ice (Jean Baptiste et al. 2001, 2003). ${ }^{4} \mathrm{He}$, a by-product of uranium series decay, remains entrapped within the rock matrix but can be released by tectonic activity. The sediments at the bottom of the lake may also be the source of ${ }^{4} \mathrm{He}$, but in this case the down core ${ }^{4} \mathrm{He}$ content of the accreted ice would increase with depth as a response to steady-state and upward He diffusion within the ice. In fact the opposite is observed, and ${ }^{4} \mathrm{He}$ concentration is higher in the upper accretion layer (Jean Baptiste et al. 2003) (Fig. 3). This suggests the possibility of a ${ }^{4} \mathrm{He}$ degassing contribution from fault vents which could be in the shallow bay located upstream of the Vostok ice core site (Fig. 3). The excess of ${ }^{4} \mathrm{He}$ found in the ca. 15000-20000 year old accretion ice suggests that tectonic activity was already operating at that time.

Third, hydrothermal area spring waters are known to be enriched with the ${ }^{18} \mathrm{O}$ isotope with respect to precipitation supplying the system (Craig 1963; Clayton \& Steiner 1975). 
This 'oxygen shift' with respect to the meteoritic water line (MWL) results from the isotope exchanges with ${ }^{18} \mathrm{O}$ rich rocks and silicates at high temperatures (Craig 1963). Lake Vostok is continuously renewed and its turnover time $(\tau)$ is 5000-100 000 years (Kapitsa et al. 1996; Jean Baptiste et al. 2001, 2003; Bell et al. 2002) which is small with respect to the likely age of the Lake ( 1000000 years or more). Assuming a mass balance, the input (i.e. melting ice) equals the output (i.e. accreted ice exported by glacier movement) and the equilibrium holds for the isotope composition of ice and water (i.e. deuterium $\delta \mathrm{D}$ and oxygen $\delta^{18} \mathrm{O}$ ). The main melting area is located $\sim 250 \mathrm{~km}$ north of Vostok, where the glacier flows down the slope from ridge B and it is thickest over the lake (Bell et al. 2002). This scenario satisfies the deuterium balance (Souchez et al. 2003). However, when compared to MWL from the Dome B ice core (Vimeux et al. 2001), a site located upstream of the melting area in Lake Vostok, accretion ice composition appears enriched in $\delta^{18} \mathrm{O}$ by $\sim 0.5 \%$ and this can be regarded as an imprint from a hydrothermal water contribution to the lake. This enrichment may explain the unusually low deuterium excess $\left(\mathrm{d}=\delta \mathrm{D}-8^{*} \delta^{18} \mathrm{O} \sim 6 \%\right.$ ) (Jouzel et al. 1999) of the accretion ice with respect to ice compositions from the Dome B and Vostok areas (minimum value $\sim 10-13 \%$ ) (Vimeux et al. 2001 and references therein), which likely supply the lake.

\section{Deliberations}

Thus, the geological setting, the long-term seismotectonic evidence from ${ }^{4} \mathrm{He}$ degassing and the ${ }^{18} \mathrm{O}$ shift' of accretion ice, all support the proposal that a geothermal environment exists beneath Lake Vostok.

Assuming that Lake Vostok is a vestige of an old continental rift system (Leitchenkov et al. 2003), seismotectonic activity has been operating locally for a long time. Local and distant tectonic events could activate fluid circulation (Dziak \& Johson 2002) and promote chemical reactions between rocks and water. Among other chemicals, hydrogen could be released (Wakita et al. 1980), and this powerful reducer could be consumed by microorganisms (Chappelle et al. 2002). Our finding of Hydrogenophilus thermoluteolus in Lake Vostok accretion ice containing sediments is consistent with such a scenario.

\section{Conclusions}

The present study attempts to estimate the microbial content of Lake Vostok accretion ice and clearly shows that in the case of low biomass, the forward-contamination of samples represents a very substantial problem. It seems that the accretion ice is essentially germ-free indicating that the water body should also be hosting a highly sparse life, if any, unless the lake water lost its biological content during the accretion process. We should also note that some terrestrial areas have already been assumed to be lifeless (Navarro-Gonzáles et al. 2003).

Of the 16 bacterial phylotypes initially recovered from the accretion ice, only one was confidently thought to be relevant to the lake while the other 15 were presumed to be contaminants. The one relevant phylotype represents a single print of life in the lake environment. The best way to avoid contamination in future studies appears to use stringent ice-chemistry-based decontamination procedures and comprehensive biological controls including establishing a contemporary contaminant database as a prerequisite to identifying and categorizing sources of extraneous cells and nucleic acids.

The very low organic carbon and nutrient content measured in accretion ice suggests conditions that are more favourable for sustaining chemoautotrophic rather than heterotrophic biota. Our finding of Hydrogenophilus thermoluteolus, a well-known thermophilic facultative chemolithoautotroph usually inhabiting hot springs, can be regarded as a strong indication for such biota. In addition, we consider its recognition exclusively from an ice interval that contains sediment inclusions as an indicator for a geothermal environment underneath the lake. Such organisms are unlikely to thrive in the open lake, where the high concentration of dissolved oxygen (up to $0.7-1.3 \mathrm{O}_{2} \mathrm{~g}^{-1}$ ) (Lipenkov \& Istomin 2001; McKay et al. 2003) is expected to be a significant constraint for at least heterotrophic life (Mikell et al. 1986). This suggests that the bacteria like $H$. thermoluteolus perhaps live at depth in 'hot' basement faults filled with sediment. It can also be speculated that such faults may have been colonized long ago, soon after their formation and/or possibly before the onset of the first Antarctic glaciation around 34000000 years ago (Barrett 2003).

The hydrothermal plumes boosted by seismotectonic events could flush out bacteria and sediments from faults towards vents in the freezing zone where the microbes may have been trapped in the ice by the process of accretion (Jouzel et al. 1999). In Lake Vostok, seismotectonic influences exist (Studinger et al. 2003) and probably sustain the geothermically fuelled biological environment beneath the lake. Such influences could provide an alternative explanation to that based on black smokers (McCollom 1999) for biological primary production.

The results of the present study have distinct implications in the search for life forms on Jovian icy moons and Mars where low microbial biomass is expected, thus, making forward-contamination by, e.g., spacecraft terrestrial bioload a rather crucial issue (Space Studies Board 2000; Chyba \& Phillips 2001). Specifically, the ice decontamination protocol developed as well as the contaminant database established in the present study represent 'lessons' for exobiology purposes.

As a guide for searching for life in subglacial environments like Lake Vostok, our criteria which are the very image of those developed for ancient DNA research (Cooper \& Poiner 2000) can be summarized as follows.

- Apply stringent ice decontamination procedures to meet the chemistry and forensic science (DNA-free) standards.

- Document the biological content of various environments (including humans) in contact with ice samples (contaminant databases). 
- Ensure that relevant biological tools (microscopy, culturing and PCR-hybridization) are used to cover all known and expected biodiversity.

- Verify microbial findings through their possible metabolic (redox) profiles taking into account the known physical and chemical features of icy environments (e.g., in Lake Vostok, no light, close to freezing point temperature, low DOC and other nutrients contents, excess of oxygen and nitrogen).

\section{Acknowledgements}

Vostok ice core samples were obtained from a 1989-1998 joint Russia, France and USA program. We acknowledge RAE, IPEV and OPP NSF for logistic support and the SPMI drilling team for fieldwork. We thank E. Coursange, S. Greilich, M. Schock, D. Faure, A. M. Gounot, A. Richaume and M. Delmotte for assistance; and J. Priscu, S. Rogers, J. C. Ellis-Evans, R. Bell, R. Psenner, W. Vincent and T. Pedersen for fruitful discussions. We would especially like to thank D. Prieur for his continuous encouragement. We also thank the reviewer for the very useful comments that helped us to improve the manuscript.

This work is a contribution to Project 4 of the Subprogram 'Study and research of the Antarctic', FTP 'World Ocean' of the Russian Federation. This research was supported by CNRS (GEOMEX), CNES and a Balzan donation by C. Lorius. S.B. and I.A. were supported by grants from CNRS (SDU and SDV) and the French Embassy in Moscow.

\section{References}

Abyzov, S.S., Mitskevich, I.N., Poglazova, M.N., Barkov, N.I., Lipenkov, V.Ya., Bobin, N.E., Koudryashov, B.B., Pashkevich, V.M. \& Ivanov, M.V. (2001). Adv. Space Res. 28, 701-706.

Altschul, S.F., Madden, T.L., Schaffer, A.A., Zhang, J., Zhang, Z., Miller, W. \& Lipman, D.J. (1997). Nucleic Acids Res. 25, 3389-3402.

Barrett, P. (2003). Nature 421, 221-223.

Barns, S.M., Delwiche, C.F., Palmer, J.D. \& Pace, N.R. (1996). Proc. Natl Acad. Sci. USA 93, 9188-9193.

Bell, R.E., Studinger, M., Tikku, A.A., Clarke, G.K.C., Gutner, M.M. \& Meertens, C. (2002). Nature 416, 307-310.

Boutron, C.F., Candelone, J.P. \& Hong, S. (1994). Geochim. Cosmochim. Acta 58, 3217-3225.

Bulat, S.A., Alekhina, I.A., Blot, M., Petit, J.-R., Waggenbach, D., Lipenkov, V.V., Raynaud, D. \& Lukin, V.V. (2002). Eos. Trans. AGU 83, (Spring Meet. Suppl.), Abstract B21A-09.

Bulat, S.A., Alekhina, I.A., Lipenkov, V.Ya., Leitchenkov, G.L., Raynaud, D. \& Petit, J.-R. (2003). In Geophysical Research Abstracts EGS-AGU-EUG Joint Assembly, vol. 5, Abstract 03288. European Geophysical Society, Nice, France.

Burggraf, S., Huber, H. \& Stetter, K.O. (1997). Int. J. Syst. Bacteriol. 47, 657-660.

Carr, M.H et al. (1998). Nature 391, 363-365.

Chappelle, F.H., O'Neill, K., Bradley, P.M., Methé, B.A., Ciufo, S.A., Knobel, L.L. \& Lovley, D.R. (2002). Nature 415, 312-315.

Christner, B.C., Mosley-Thompson, E., Thompson, L.G. \& Reeve, J.N. (2001). Environ. Microbiol. 3, 570-577.

Chyba, C.F. \& Phillips, C.B. (2001). Proc. Natl Acad. Sci. USA 98, 801-804.
Cisar, J.O., Xu, D.Q., Thompson, J., Swaim, W., Hu, L. \& Kopecko, D.J. (2000). Proc. Natl. Acad. Sci. USA 97, 11511-11515.

Clayton, R.N. \& Steiner, A. (1975). Geochem. Cosmochem. Acta 39, $1179-1186$.

Cooper, A. \& Poinar, H.N. (2000). Science 289, 1139.

Corless, C.E., Guiver, M., Borrow, R., Edwards-Jones, V., Kaczmarski, E.B. \& Fox, A.J. (2000). J. Clin. Microbiol. 38, 1747-1752.

Craig, H. (1963). The isotopic geochemistry of water and carbon in geothermal areas. In Nucelar Geology of Geothermal Areas, pp. 1-53. Spoleto, Consiglio Nationale dell Ricerche, Laboratorio di Geologia Nucleare, Pisa.

Crocetti, G.R., Hugenholtz, P., Bond, P.L., Schuler, A., Keller, J., Jenkins, D. \& Blackall, L.L. (2000). Appl. Environ. Microbiol. 66, 1175-1182.

DeLong, E.F. (1992). Proc. Natl Acad. Sci. USA 89, 5685-5689.

Dunbar, J., Barns, S.M., Ticknor, L.O. \& Kuske, C.R. (2002). Appl. Environ. Microbiol. 68, 3035-3045.

Dziak, R.P. \& Johson, H.P. (2002). Science 296, 1406-1407.

Godon, J.-J., Zumstein, E., Dabert, P., Habouzit, F. \& Moletta, R. (1997). Appl. Environ. Microbiol. 63, 2802-2813.

Goto, E., Kodama, T. \& Minoda, Y. (1977). Agric. Biol. Chem. 41, 685-690.

Grahn, N., Olofsson, M., Ellnebo-Svedlund, K., Monstein, H.-J. \& Jonasson, J. (2003). FEMS Microbiol. Lett. 219, 87-91.

Hayashi, N.R., Ishida, T., Yokota, A., Kodama, T. \& Igarashi, Y. (1999). Int. J. Syst. Bacteriol. 49, 783-786.

Higgins, D., Thompson, J., Gibson, T., Thompson, J.D., Higgins, D.G. \& Gibson, T.J. (1994). Nucleic Acids Res. 22, 4673-4680.

Huber, H., Hohn, M.J., Rachel, R., Fuchs, T., Wimmer, V.C. \& Stetter, K.O. (2002). Nature 417, 63-67.

Hugenholtz, P., Pitulle, C., Hershberger, K.L. \& Pace, N.R. (1998) J. Bacteriol. 180, 366-376.

Ikeda, T., Salamatin, A.N., Lipenkov, V.Ya. \& Hondoh, T. (2000). In Physics of Ice Core Records, ed. Hondoh, T., pp. 393-421. Hokkaido University Press, Sapporo.

Imhoff, J.F. (2003). The phototrophic beta-Proteobacteria. In The Prokaryotes: An Evolving Electronic Resource for the Microbiological Community, release 3.13, ed. Dworkin, M. et al., May 12, 2003. Springer, New York. http://link.springer-ny.com/link/service/books/10125/

Jean Baptiste, P., Petit, J.R., Lipenkov, V.Ya., Raynaud, D. \& Barkov, N.I. (2001). Nature 411, 460-462.

Jean Baptiste, P., Petit, J.R., Raynaud, D., Jouzel, J. \& Bulat, S. (2003). In Geophysical Research Abstracts EGS-AGU-EUG Joint Assembly, vol. 5, Abstract 08205. European Geophysical Society, Nice, France.

Jouzel, J., Petit, J.R., Souchez, R., Barkov, N.I., Lipenkov, V.Ya., Raynaud, D., Stievenard, M., Vassiliev, N.I., Verbeke, V. \& Vimeux, F. (1999). Science 286, 2138-2141.

Kapitsa, A.P., Ridley, J.F., Robin, G.de.Q., Siegert, M.J. \& Zotikov, I.A. (1996). Nature 381, 684-686.

Karl, D.M., Bird, D.F., Björkman, K., Shackelford, R., Houlihan, T. \& Tupas, L. (1999). Science 286, 2144-2147.

Kawai, M., Matsutera, E., Kanda, H., Yamaguchi, N., Tani, K. \& Nasu, M. (2002). Appl. Environ. Microbiol. 68, 699-704.

Kulakov, L.A., McAlister, M.B., Ogden, K.L., Larkin, M.J. \& O’Hanlon, J.F. (2002). Appl. Environ. Microbiol. 68, 1548-1555.

Kuske, C.R., Barns, S.M. \& Busch, J.D. (1997). Appl. Environ. Microbiol. 63, 3614-3621.

Legrand, M., de Angelis, M. \& Maupetit, F. (1993). J. Chromatography 640, 251-258.

Legrand, M. \& Mayewski, P. (1997). Rev. Geophys. 35, 219-243.

Legrand, M. \& Saigne, C. (1988). Atmos. Environ. 22, 1011-1017.

Leitchenkov, G.L., Masolov, V.N., Lukin, V.V., Bulat, S.A., Kurinin, R.G. \& Lipenkov, V.Ya. (2003). In Geophysical Research Abstracts EGS$A G U-E U G$ Joint Assembly, vol. 5, Abstract 03433. European Geophysical Society, Nice, France.

Lipenkov, V.Ya. \& Istomin, V.A. (2001). Mater. Glyatsiol. Issled. 91, 138-149.

Lipenkov, V.Ya., Istomin, V.A., Bulat, S.A., Raynaud, D. \& Petit, J.R. (2002). Eos. Trans. $A G U \mathbf{8 3}$ (Spring Meet. Suppl.), Abstract B21A-06. 
López-García, P., Duperron, S., Philippot, P., Foriel, J., Susini, J. \& Moreira, D. (2003). Environ. Microbiol. 5, 961-976.

Lueders, T. \& Friedrich, M.W. (2003). Appl. Environ. Microbiol. 69, 320-326.

Masolov, V.N., Lukin, V.V., Sheremetiev, A.N. \& Popov, S.V. (2001) Dokl. Earth Science 379A, 734-738.

McCollom, T.M. (1999). J. Geophys. Res. 104, 30 729-30 742.

McGregor, D.P., Forster, S., Steven, J., Adair, J., Leary, S.E.C., Leslie, D.L., Harris, W.J. \& Titball, R.W. (1996). BioTechniques 21, 463-471.

McKay, C.P., Hand, K.P., Doran, P.T., Andersen, D.T. \& Priscu, J.C. (2003). Geophys. Res. Lett. 30, 35-1-35-4.

Mikell, A.T., Jr., Parker, B.C. \& Gregory, E.M. (1986). Appl. Environ. Microbiol. 52, 1236-1241.

Millar, B.C., Xu, J. \& Moore, J.E. (2002). J. Clin. Microbiol. 40, 1575-1580.

Muyzer, G., de Waal, E.C. \& Uitterlinden, A.G. (1993). Appl. Environ. Microbiol. 59, 695-700.

Navarro-Gonzáles, R., et al. (2003). Science 302, 1018-1021.

Pappalardo, R.T., et al. (1999). J. Geophys. Res. 104, 24015-24 055.

Pearson, W.R. (1990). Methods Enzymology 183, 63-98.

Petit, J.R. (2003). In Geophysical Research Abstracts EGS-AGU-EUG Joint Assembly, vol. 5, Abstract 03628. European Geophysical Society, Nice, France.

Petit, J.R., Blot, M. \& Bulat, S. (2003). In L'Environnement de la Terre primitive, ed Despois, D., Gargaud, M. \& Parisot, J.-P., pp. 273-316. Presses Universitaires de Bordeaux, Bordeaux.

Petit, J.R., et al. (1999). Nature 339, 429-436.

Price, P.B. (2000). Proc. Natl Acad. Sci. USA 97, 1247-1251.

Priscu, J.C., et al. (1999). Science 286, 2141-2144.
Rummel, J.D. (2001). Proc. Natl Acad. Sci. 98, 2128-2131.

Salamatin, A.N., Petit, J.R. \& Lipenkov, V.Ya. (2003). In Geophysical Research Abstracts EGS-AGU-EUG Joint Assembly, vol. 5, Abstract 08277. European Geophysical Society, Nice, France.

Siegert, M.J. (2000). Earth Sci. Rev. 50, 29-50.

Siegert, M.J. (2001). Polar Geography 24, 289-301.

Siegert, M.J., Ellis-Evans, J.C., Tranter, M., Mayer, C., Petit, J.R., Salamatin, A.N. \& Priscu, J.C. (2001). Nature 414, 603-609.

Souchez, R., Petit, J.R., Jouzel, J., DeAngelis, M. \& Tison, J. (2003). Earth Planet. Sci. Lett. 217, 163-170.

Space Studies Board (2000). Preventing the Forward Contamination of Europa. National Academy of Science Press, Washington, DC.

Stackebrandt, E. \& Goebel, B.M. (1994). Int. J. Syst. Bacteriol. 44, 846-849.

Stohr, R., Waberski, A., Liesack, W., Volker, H., Wehmeyer, U. \& Thomm, M. (2001). Int. J. Syst. Evol. Microbiol. 51, 481-488.

Studinger, M., et al. (2003). Earth Planet Sci. Lett. 205, 195-210.

Swaty, R.L., Gehring, C.A., Van Ert, M., Theimer, T.C., Keim, P. \& Whitham, T.G. (1998). New Phytol. 139, 733-739.

Teske, A., Wawer, C., Muyzer, G. \& Ramsing, N.B. (1996). Appl. Environ. Microbiol. 62, 1405-1415.

Tanner, M.A., Goebel, B.M., Dojka, M.A. \& Pace, N.R. (1998). Appl. Environ. Microbiol. 64, 3110-3113.

Vimeux, F., Masson, V., Jouzel, J., Petit, J.R., Steig, E.J., Stievenard, M., Vaikmae, R. \& White, J.W.C. (2001). Climate Dynam. 17, 503-513.

Vincent, W.F. (1999). Science 286, 2094-2095.

Vincent, W.F. (2000). Antarctic Sci. 12, 374-385.

Wakita, H., Nakamura, Y., Kita, I., Fujii, N. \& Notsu, K. (1980). Science 210, $188-190$. 